\title{
Шестакова А.А. \\ Геокриологические условия территории мостового перехода через р. Лена
}

ФГБУН Институт мерзлотоведения им. П.И. Мельникова СО РАН

(Россия, Якутск)

doi: $10.18411 / \mathrm{j}-07-2021-68$

\section{Аннотация}

В статье приведены геокриологические условия района планируемого мостового перехода через р. Лена - распространение средних годовых температур многолетнемерзлых пород, таликов и мерзлотно-геологических процессов, и явлений и мощность деятельного слоя. Проведен количественный анализ закономерностей пространственного распределения мерзлотных характеристик. Составлена карта-схема распространения таликов. Изучение геокриологических условий послужило для дальнейшего составления геокриологической карты мостового перехода через р. Лена в районе г. Якутска масштаба 1:5000.

Ключевые слова: геокриологические условия, температура грунтов, деятельный слой, криогенные процессы, талик, р. Лена.

\section{Abstract}

The article presents the geocryological conditions of the area of the planned bridge crossing over the Lena river - the distribution of average annual temperatures of permafrost, taliks and permafrost-geological processes, and phenomena and the thickness of the active layer. A quantitative analysis of the regularities of the spatial distribution of permafrost characteristics has been carried out. A schematic map of the distribution of taliks has been compiled. The study of geocryological conditions served for the further compilation of a Geocryological map of the bridge over the Lena river in the area of Yakutsk on a scale of 1:5,000.

Keywords: geocryological conditions, soil temperature, active layer, cryogenic processes, talik, Lena river.

Территория Республики Саха (Якутия) достаточно хорошо изучена в геокриологическом отношении. Геокриологические условия - температура грунтов, мощность деятельного слоя и распространение криогенных процессов имеют важное значение для оценки состояния территорий с развитием вечной мерзлоты. Это необходимо для устойчивого социально-экономического развития, оценки экологического состояния территорий в условиях современных изменений климата и усиления антропогенного воздействия на природную среду.

Температура горных пород наиболее важная характеристика для изучения не только современного состояния ландшафтов, но и их динамики. Изменение температуры грунтов приводит к активизации криогенных процессов, что является основным критерием устойчивости ландшафтов. Так, например, в последние три десятилетия, повышение температуры грунтов на $1^{\circ} \mathrm{C}$ на безлесных ландшафтах в Центральной Якутии привело к вытаиванию верхних оголовков повторно-жильных льдов, что вызвало массовое развитие термокарста [1]. На территории России, занятой вечной мерзлотой, за период 1965-2005 гг. были характерны значения линейных трендов средней годовой температуры грунтов от 0,01 до $0,04^{\circ} \mathrm{C}$ в год [2].

На рассматриваемой территории выделено 16 интервалов значений температуры грунтов. Следует отметить, что пространственная дифференциация температуры горных пород достаточно разнообразная. Температурные данные были объединены в 4 группы (рис. 1). 


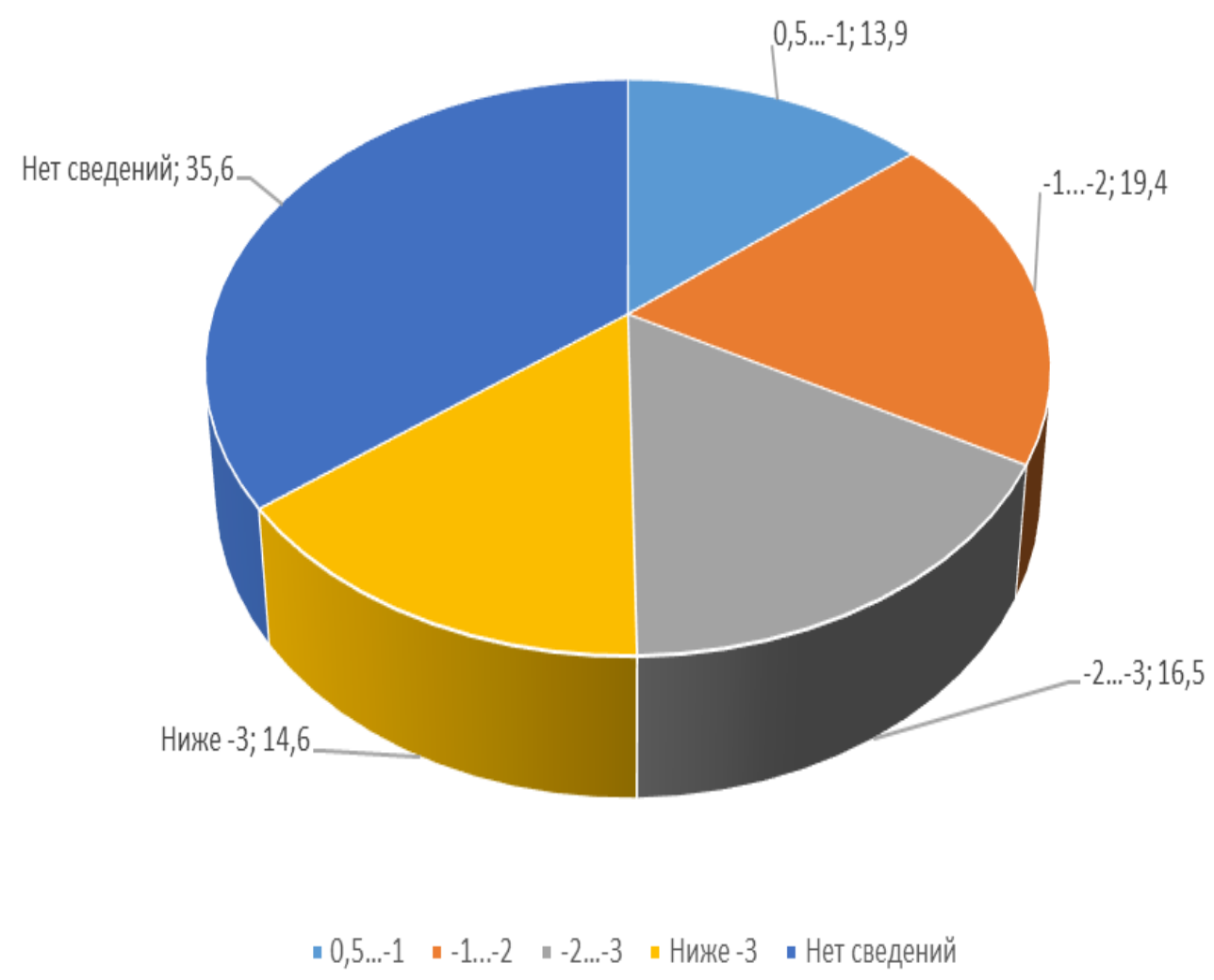

Рис. 1. Пространственное распределение значений температуры грунтов.

Так, ландшафты с переходными температурами грунтов от 0,5 до $-1^{\circ} \mathrm{C}$ занимают 13,9 \% территории. Наиболее распространены высокотемпературные мерзлотные ландшафты (температура от -1 до $-2{ }^{\circ} \mathrm{C}$ ), которые занимают $19,4 \%$ территории. Среднетемпературные ландшафты (температура грунтов от -2 до $-3{ }^{\circ} \mathrm{C}$ ) составляют 16,5 $\%$ и низкотемпературные (температура грунтов ниже $-3{ }^{\circ} \mathrm{C}$ ) занимают $14,6 \%$. Около 36 $\%$ территории мостового перехода не содержит сведений о температуре грунтов.

На рассматриваемой территории имеются подозерные и старичные талики, а также сквозные талики под руслом р. Лены, они занимают $16 \%$ рассматриваемой территории. На карта-схеме распространения таликов (рис. 2) выделено 5 таликовых зон на территории мостового перехода через р. Лена: I зона - несквозные талики мощностью менее 10 м; II зона - несквозные талики мощностью более 10 м; III зона талики несквозные, возможно сквозные мощностью более 10 м; IV зона - несквозные талики мощностью более 10 м, а также с отдельными таликами мощностью до 20 м под руслами и протоками малых рек; V зона - талик сквозной под руслом р. Лены.

В аллювиальных отложениях обнаружены надмерзлотные (интервал глубины залегания 2,6-8,0 м) и межмерзлотные (интервал глубины залегания 10,5-13,2 м) водоносные талики малой мощности. Так, у левого берега реки Лены всеми скважинами вскрыт надмерзлотный водоносный талик с глубины 1,5-2,1 м. Мощность его 1-1,7 м. Участок от 7,15-7,80 км (эстакадная опора) занимает среднюю и высокую пойму. В средней пойме с глубины 2,5-3,0 м широко распространены надмерзлотные талики. Температура талых грунтов в слое годовых теплооборотов от 0,0 до $1,4{ }^{\circ} \mathrm{C}$. В аллювиальных отложениях средней поймы широко распространены надмерзлотные водоносные талики. Они обнаружены почти на 50 \% площади между руслом р. Лены и Хаптагайской протокой и вскрыты вблизи стариц р. Тамма. Кровля надмерзлотных таликов залегает на глубине от 2 до 5,7 м, мощность изменяется от 2,5 до 8 и более метров. Отдельными скважинами вскрыты талые водоносные перезимки в интервале глубин от 2,0-2,5 до 2,5-2,7 м. 


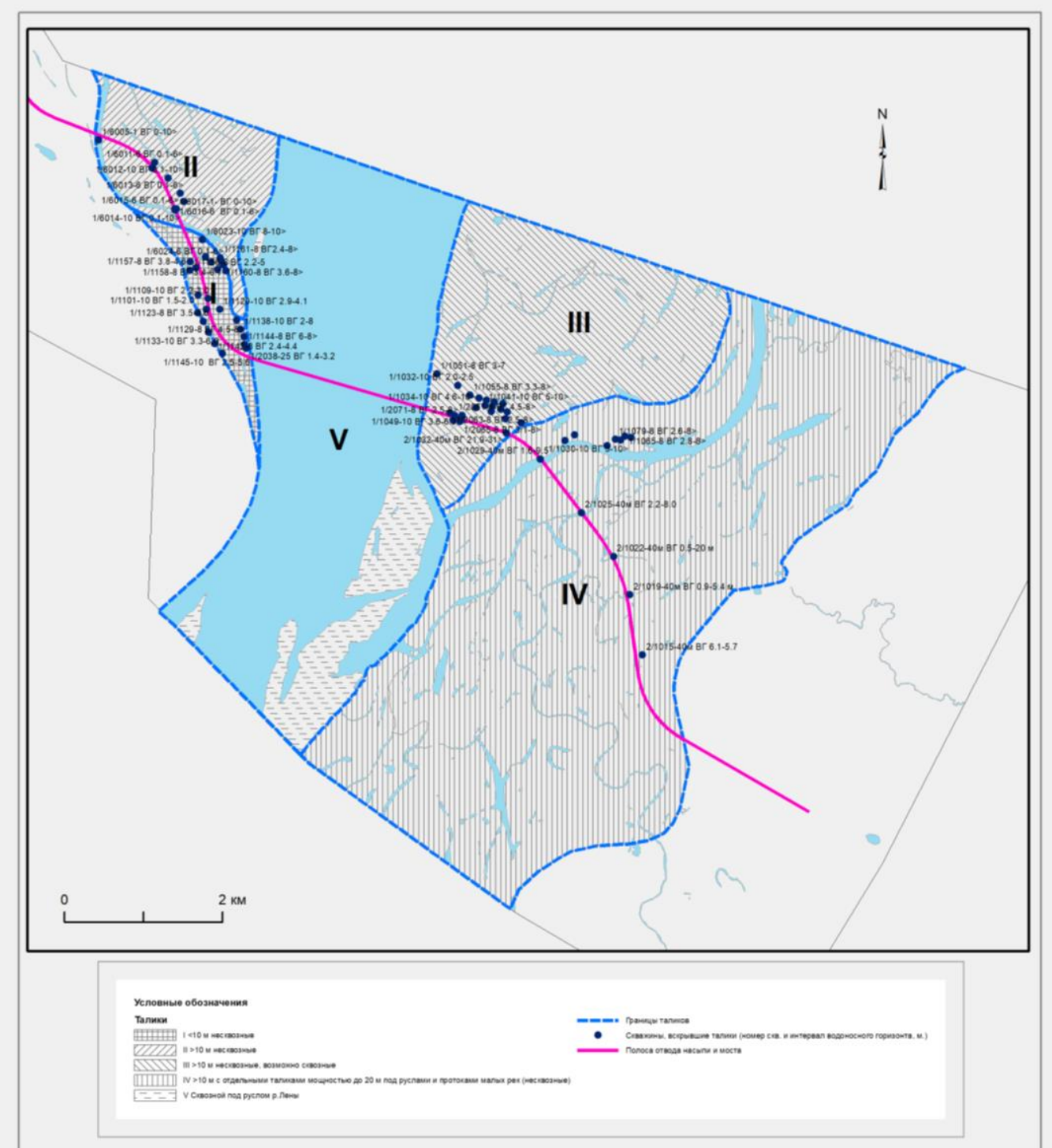

Рис. 2. Карта-схема распространения таликов на территории мостового перехода через р. Лена.

Температура грунтов в таликах на глубине 10 м варьирует в пределах 0,0-2,4 ${ }^{\circ} \mathrm{C}$. В аллювиальных отложениях на участках старичных понижений распространены водонасыщенные талики мощностью около 6 м. Плановые границы таликов не выходят за пределы водной поверхности старичных озер и проток.

Мощность деятельного слоя состоит из сезонно-талого и сезонно-мерзлого слоев и является одной из наиболее динамичных характеристик криолитозоны. Значения мощности деятельного слоя неразрывно связаны с изучением динамики ландшафтов в области вечной мерзлоты. Увеличение и уменьшение ее параметров может привести к большим изменениям в структуре ландшафтов. Запасы влаги, биопродуктивность ландшафтов, активизация криогенных процессов и другие особенности ландшафтов в первую очередь зависят от изменения мощности деятельного слоя. Якутия входит в мировую систему мониторинга за динамикой мощности деятельного слоя CALM [3].

На территории мостового перехода выделено 5 групп значений мощности деятельного слоя. Наиболее распространены ландшафты со значениями мощности деятельного слоя более 2 м, они занимают 43,5 \% территории. Ландшафты со значениями глубин СТС 0,5-1,0 м, 1,0-1,5 м, 1,5-2,0 м занимают 1,2 \%, 12,5 \% и 6,6 \% соответственно рассматриваемой территории. Незначительные территории - $0,5 \%$ занимают ландшафты со значениями мощности деятельного слоя менее 1 м. Территории, не имеющие сведения о значениях глубин СТС, составляют 19 \% (рис. 3). 


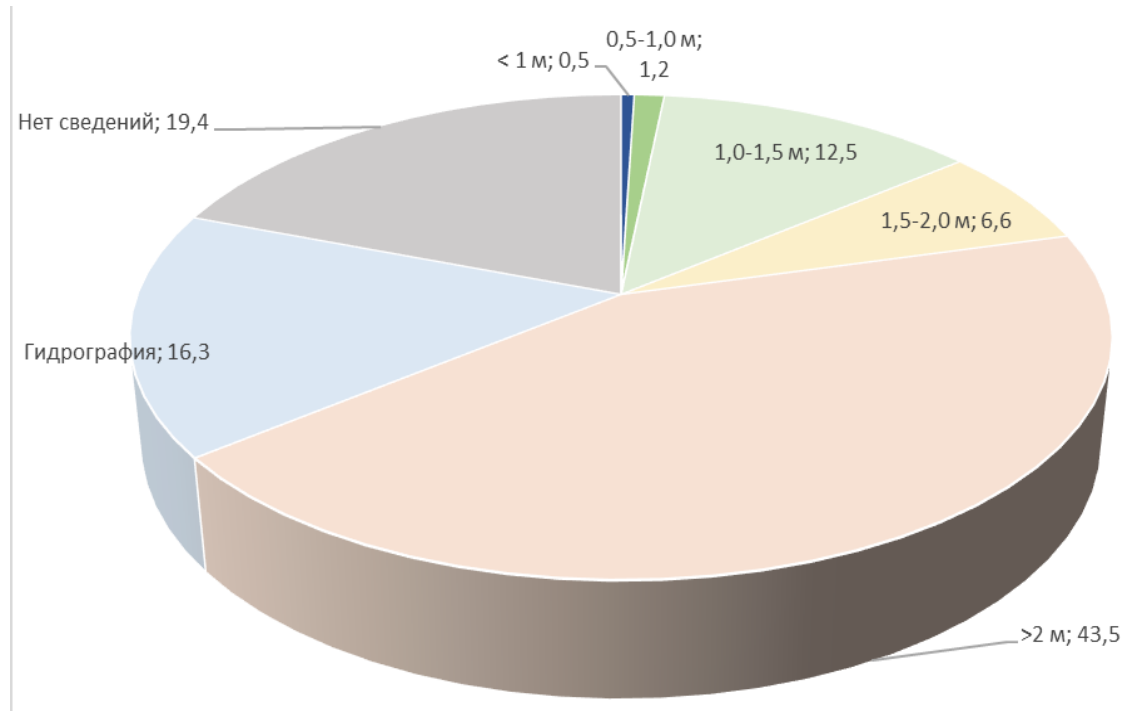

Рис. 3. Пространственное распределение глубины деятельного слоя.

Интенсивность развития, распространенность и пораженность криогенными процессами является одним из основных показателей оценки состояния многолетнемерзлых пород. Криогенные процессы тесно взаимосвязаны с льдистостью отложений, так же, как и с поверхностными отложениями. Слабая льдистость отложений большинства ландшафтов рассматриваемого района предполагает ограниченное развитие криогенных процессов.

На пойме и высокой пойме мелких рек развиваются боковая эрозия берега, морозобойное растрескивание наряду с эоловыми и русловыми процессами, и заболачиванием. На низкой, средней, высокой поймах крупных рек и низкотеррасовом типе местности также наблюдается боковая эрозия берега, морозобойное растрескивание и отчасти пучение, и термокарст в виде полигональных просадок. На пашнях, просеках, вырубках и гарях, находящихся на средневысотных террасах и древнетеррасовом типе местности, развиты термопросадки на переувлажненных участках. На сырых лугах осоково-вейниковых происходит процесс заболачивания. Достаточно опасен также склоновый на коренных берегах тип местности, где получили развитие термоэрозия, морозобойное растрескивание, солифлюкция на средней и нижней части склона. На юго-западе территории мостового перехода наблюдается активное морозобойное трещинообразование.

Результаты количественного анализа закономерностей пространственного распределения геокриологических условий в дальнейшем следует использовать при проектировании мостового перехода через р. Лена в районе г. Якутска.

$$
* * *
$$

1. Fedorov, A.N., Ivanova, R.N., Park, H., Hiyama, T., Iijima, Y. 20146. Recent air temperature changes in the permafrost landscapes of northeastern Eurasia, POLAR SCIENCE, Vol. 8, Issue 2, 114-128. DOI://DX.DOI.ORG/10.1016/J.POLAR.2014.02.001.

2. Павлов А.В., Малкова Г.В. Мелкомасштабное картографирование трендов современных изменений температуры грунта на Севере России // Криосфера Земли, 2009. - Т. 13. - Вып. 4. - С. 32-39.

3. Nelson, F.E., Shiklomanov, N.I., Christiansen, H.H., Hinkel, K.M. 2004. The circumpolar active layer monitoring (CALM) Workshop: Introduction. Permafrost and periglacial processes, 15, 2, 99-101. DOI: $10.1002 /$ ppp.488. 